\title{
DO MODELO À AÇÃO: A POLÍTICA EM SÊNECA E O ELOGIO DA FILOSOFIA
}

\author{
Taynam Santos Luz Bueno ${ }^{1}$
}

Resumo: Neste artigo, pretendemos demonstrar que o estoicismo não é uma filosofia apartada da ação política mas, ao contrário, trata-se de uma corrente filosófica comprometida com a esfera pública. Buscamos, ao exaltar o papel exercido pela filosofia na formação política dos homens comuns, analisar o pensamento de Sêneca tendo em vista a relação estabelecida entre a figura modelar do sapiens estoico e o ofício do filósofo na construção de um campo de ação político.

Palavras-Chave: Sêneca - Estoicismo - Filosofia - Sapiens - Política.

À Maria das Graças de Souza.

Sabe-se que, durante muito tempo, a questão política fora negligenciada pelos intérpretes da stoa. Muito frequentemente se creditou ao estoicismo uma posição de indiferença, alheia à vida comum e aos assuntos públicos, sem mencionar as constantes críticas dirigidas às supostas contradições entre sua ética e a possibilidade de realização da política. Muito desta interpretação do estoicismo fundamenta-se ora nos registros doxográficos legados à posteridade, ora na construção da imagem do sábio (sapiens -

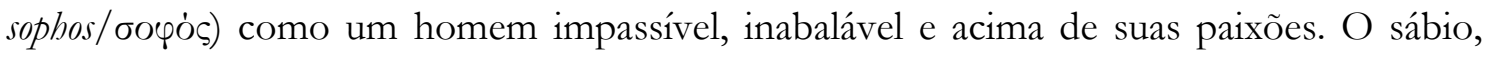
compreendido enquanto uma espécie de "semi-deus", viveria, sob o ponto de vista desta leitura, recluso e apartado do mundo, encerrado em si mesmo e insensível aos sofrimentos mundanos. Seria aquele que bastaria a si mesmo, ainda que em um cataclismo. Tal homem, considerado um modelo a ser seguido, espécie de exemplo inalcançável, não padeceria, não teria sentimentos e seria absolutamente indiferente ao mundo que o cerca. Levando a cabo este viés interpretativo estaríamos, portanto, admitindo uma corrente filosófica apolítica, absolutamente indiferente aos regimes, governantes e corpos políticos. Consequentemente, tal forma de exposição da doutrina estoica, presume que o sábio não tenha outra preocupação além de seu ostracismo ignóbil e insensível, o pintaria sempre entregue e retirado ao seu ócio

1 Doutoranda do departamento de Filosofia da Universidade de São Paulo - USP. E-mail: taynambueno@hotmail.com.. Bolsista FAPESP. 
especulativo, apartando-o, portanto, das possíveis discussões políticas que o circundassem. No entanto, como pretendemos demonstrar, não somente as questões políticas possuem lugar no pórtico, como são imprescindíveis em seu pensamento. Afinal, pensar o estoicismo nestes termos reduz inevitavelmente a importância das questões políticas na doutrina, pois ao afastar o sábio e sua modelar virtude dos assuntos da res publica, faz com que o político seja eclipsado do horizonte desta filosofia.

Ao contrário disso, acreditamos que não seja possível conciliar tal interpretação defensora do apolitismo da escola com a já conhecida participação e interesse de filósofos estoicos na política ${ }^{2}$, bem como seria impossível negligenciar o papel da política na reflexão ética estoica. O que é preciso, antes de anular o universo político da filosofia da stoa, é diferenciar, em seu discurso, sua perspectiva modelar de seus apontamentos gerais. Ora, para bem compreendermos os ensinamentos estoicos, devemos sempre ter em mente que seu discurso possui meandros e sua interpretação requer cuidados. Que o estoicismo, durante muitos séculos, fora por muitas vezes interpretado como escola apolítica, disso não temos dúvida. No entanto, uma análise mais atenta pode nos oferecer outro caminho para sua interpretação. A questão política, na filosofia estoica, ao contrário do que muitos pensaram, sempre obteve espaço nos debates e sempre foi alvo de discussões, desde o início da escola. Zenão de Cítio, seu fundador, tem entre os seus escritos um texto intitulado República, que infelizmente não foi preservado. Tal texto, talvez o mais famoso e comentado do fundador do estoicismo, parece dialogar com o texto platônico de mesmo nome, ainda que não saibamos corretamente se Zenão alinhava-se ou não às propostas do filósofo grego. O que nos importa, ainda assim, é constatar que a política orbitava entre os temas de interesse da escola, desde sua fundação. Crisipo escreveu Sobre os governos?. Panécio escreveu sobre as magistraturas, Diógenes da Babilônia sobre as leis ${ }^{4}$, Atenodoro de Tarso e Ário Dídimo foram mestres de Otaviano ${ }^{5}$, o primeiro dos imperadores romanos. Sêneca nos deixou

\footnotetext{
${ }^{2}$ Desde seu início, a stoa demonstrou interesse na política. Para citar alguns exemplos, Zenão de Cítio, (considerado o criador da doutrina estoica em aproximadamente 300 a.C), mesmo não tendo participação direta na política, ao ser soliciado por Antígono Gonatas, então rei da Macedônia, enviou em seu lugar seus discípulos, alegando estar muito velho para a tarefa. Sêneca, como sabemos, após cumprir o cursus honorum romano, foi preceptor de Nero e seu conselheiro durante o início de seu governo. Marco Aurélio foi imperador de Roma do ano 161 até sua morte, em 180, e dividiu-se entre o império e seus estudos filosóficos. Muitos outros filósofos tiveram interesse, atuaram na oposição de governos ou na participação direta na política romana, como Mussônio Rufo, Thrasea Paetus e Catão de Útica. Para conhecer o papel da Stoa na política helenística c.f: DIÓGENES LAÉRCIO, Vidas e doutrinas dos filósofos ilustres. VII, 6 e ERSKINE, A. The helleistic Stoa: political thought and action. p. 80.

${ }^{3}$ DIÓGENES LAÉRCIO, Vidas e doutrinas dos filósofos ilustres. VII, 131

${ }^{4}$ CÍCERO, Das Leis. (De Legibus). III, 5-6.

${ }^{5}$ C.f.: DIÃO CÁSSIO; História Romana, Séc. III, II, 16 e PLUTARCO; Vidas Paraleas, Vida de Marco Antônio, I, 80 .
} 
diversas obra nas quais a preocupação política é evidente. Especificamente no caso deste último, suas consolações, alguns de seus diálogos (com atenção especial ao De Clementia) e em textos como De Ira e Epistulae Morales ad Lucilium, revelam o persistente interesse dos estoicos na res publica, na política e na vida em comum. Além do mais, não se deve esquecer Marco Aurélio, que além de filósofo estoico tornou-se imperador romano. O estoicismo e seus filósofos, por conseguinte, sempre manifestaram interesse na política; fato que deslegitimaria, em grande parte, a interpretação que considera o pórtico como escola apartada dos assuntos da res publica. Mas não somente este interesse garante espaço à política na ética estoica. Existem diversos outros fatores que merecem nossa atenção.

De modo a evitar equívocos, convém deixar claro que muitas opiniões acerca do estoicismo são baseadas não nas obras de seus filósofos, mas nos relatos de historiadores, doxógrafos, biógrafos e adversários da stoa $a^{6}$. O estado fragmentário de muitos textos, a inexistência completa de outros, as apropriações, reinterpretações e cópias manuscritas ao longo dos séculos, o descrédito que alguns exemplos históricos deixaram, enfim; tudo isso contribuiu para a formação equivocada desta imagem de apolitismo e indiferença da escola. No caso de Sêneca e sua tortuosa experiência com Nero, por exemplo, o legado histórico comumente propagado é aquele em que um princeps educado para a virtude transforma-se em um governante tirânico e violento. Em outras palavras, um legado malogrado de intervenção política por parte do pórtico. No entanto, no que pouco se insiste é que, apesar do insucesso de Sêneca em formar Nero para um governo justo e virtuoso, os cinco primeiros anos de seu governo - justamente aqueles em que Sêneca teve participação direta e determinante - são considerados anos de ouro do império ${ }^{7}$. Além do mais, avaliar a importância da política na filosofia estoica por meio de seus exemplos históricos revela desconhecimento quanto ao funcionamento mesmo da ética estoica, na qual uma ação não adquire seu valor moral pelos resultados que obteve, mas sim pela intenção que a motivou. Em outras palavras, dentro do estoicismo, se Nero progrediu para a virtude ou não, não é passível de julgamento, pois não se avalia as ações por seus fins, mas por elas mesmas. Ações virtuosas, nascem virtuosas. Diz o autor romano: "Além disso o sábio pode responsabilizar-se pelas suas decisões, não pelo sucesso das mesmas. Se o início [das ações] depende de nós, o resultado depende da fortuna." ${ }^{8}$ Neste sentido, o realmente importante neste exemplo histórico é a intenção de Sêneca, sua tentativa de tornar Nero um governante virtuoso. Não estamos, portanto, diante de uma ética de resultados. O estoicismo, por fim, não julga uma ação pelo seu êxito, mas

\footnotetext{
${ }^{6}$ É o caso, apenas para ilustrar, de Plutarco com o texto De stoicorum repugnantiis, no qual o autor não preocupase em demonstrar a doutrina, mas sim em apontar-lhe contradições, muitas vezes fruto de uma má interpretação por parte de Plutarco.

${ }^{7}$ Fala-se aqui daquilo que os historiadores chamam quinquennium neronis, ou os cinco primeiros anos do governo de Nero, tidos como justos e com grande desenvolvimento e estabilidade em Roma.

${ }^{8}$ Sêneca, Epist. 14, 15.
} 
por seu início, uma vez que a ação reta é produzida pela sabedoria ${ }^{9}$. Uma ação moral, quando correta e virtuosa, o é desde seu princípio, desde a inclinação primeira de seu agente. Afinal, como nos diz Sêneca, "Uma ação não pode ser correta se não for correta a vontade, pois é desta que provém a ação." ${ }^{10}$ Finalmente, não devemos mensurar a importância da política no estoicismo por meio de seus resultados históricos, mas sim pelo interesse inerente de sua filosofia nestas questões. Em outras palavras, não se deve pautar a filosofia política estoica apenas por seus exemplos históricos. É preciso ir além. É preciso compreender sua ética para afirmar sua posição.

Para além disso, a comum imagem do sábio estoico, pintado de forma sentimentalmente estéril, também corrobora tal interpretação. Mas, não nos deixemos enganar: a impassibilidade do sábio não se traduz como indiferença ao político. Lembremos da sentença de Plutarco, que nos relata que Crisipo, sistematizador do estoicismo, dizia que "o sábio participará da vida política se nada o impedir" ${ }^{11}$. Ao sábio, portanto, é aberta a possibilidade da política, apesar de sua denominação enquanto indiferente (adiaphora - indifferens) ${ }^{12}$ para o alcance da vida feliz. Mesmo a política sendo considerada um indiferente para a aquisição da virtude e para a manutenção da felicidade do sábio, ainda assim os mestres estoicos recomendam a sua participação na coisa pública. Além do mais, a impassibilidade do sábio não se traduz como ausência de sentimentos, mas sim como controle dos mesmos ${ }^{13}$. O sábio, assim como todos os outros homens, sente dor, frio, calor, amor, etc. No entanto,

\footnotetext{
${ }_{9}^{9}$ Cícero, De Finibus. III, 32.

${ }^{10}$ SÊNECA, Epist. 95, 57.

11 PLUTARCO, De stoicorum repugnantiiis. 1045D

${ }^{12} \mathrm{Na}$ ética estoica, somente a virtude possui valor absoluto. Todo o resto é considerado indiferente (tudo aquilo que não possui valor em si mesmo, por exemplo, como riqueza, saúde, pobreza e etc.). Entre os indiferentes, os estoicos dividem três tipos distintos: os que estão de acordo com a natureza e são, portanto, preferíveis. Em segundo lugar, os absolutamente indiferentes porque não estão nem contra, nem a favor da natureza (se o número de cabelos é par ou ímpar, por exemplo) e, por fim, os indiferentes que devem ser rejeitados por não estarem de acordo com a natureza. No entanto, vale lembrar que os indiferentes configuram uma escala de valores relativos e que somente o sapiens poderá efetivamente saber quando uma ação será preferível ou não. Por exemplo, em uma tirania que convoque todos os homens saudáveis para uma batalha injusta, seria mais adequado não ter saúde. Somente o sábio, por ter suas ações perfeitas, saberia quando seria melhor ter saúde ou estar doente. Já os homens comuns, por sua vez, devem pautar-se pelos indiferentes preferíveis, realizando ações comuns alinhadas aos deveres (kathekon, officium), como, por exempl, honrar a pátria e defender os familiares das injustiças.

${ }^{13}$ Da mesma forma que o sapiens não prefere a solidão. O homem é, para os estoicos, um animal social antes

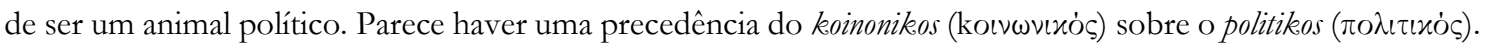
BANATEANU, Anne. La théorie stoïcienne de l'amitié. Essai de reconstruction. p. 102
} 
diferentemente dos homens comuns, os sábios não sucumbem a eles ${ }^{14}$. É o que nos diz o autor romano:

"Para que te não pareça que a virtude estoica paira para além do humanamente possível, dir-te-ei que o sábio também pode estremecer, sofrer, perder a cor, pois tudo isso são sensações fisicamente naturais." ${ }^{\prime 15}$

Talvez a grande dificuldade seja a tradução do vocábulo grego $\dot{\alpha} \pi \dot{\alpha} \theta \varepsilon ı \alpha$ (apatheia) para a língua latina, motivo de muitos mal-entendidos na compreensão do sábio estoico. Traduzido normalmente por impatientia em latim, o termo grego apatheia pode significar tanto a ausência de pathos (sofrimento, afecção, paixão), quanto a invulnerabilidade do ânimo frente ao pathos. Por impatientia, Sêneca pretende "aludir a alguém capaz de repelir o sentimento da dor" mas, lembra o autor, "a palavra pode entender-se como significando a incapacidade de suportá-la." "16 Nesta segunda acepção, o termo é erroneamente compreendido, pois tal interpretação levará a pensar o sábio como aquele que evita todo o sofrimento, dada sua incapacidade de suportá-lo. Neste sentido, nosso autor questiona se não seria "preferível falarmos em invulnerabilidade do ânimo (invulnerabilem animum), ou em ânimo situado para lá de todo sofrimento (animum extra omnem patientiam positum)"17, de modo a evitar tal equívoco. Esta diferença vocabular interfere diretamente na interpretação do sábio estoico, já que pode ser erroneamente entendido como aquele que não possui sentimentos, quando, na verdade, o sábio estoico sente, mas não sucumbe a eles. Ainda sobre essa questão, nosso filósofo trata de diferenciar a proposta estoica da cínica, dizendo que "A diferença entre a nossa escola [estoica] e a deles [cínicos - recuperados aqui por uma crítica feita por Epicuro à Estilbão, filósofo megárico do séc. III a.C] é que o sábio, na nossa concepção, embora o sinta, domina todo o sofrimento, na deles, nem sequer o sente."18 Talvez, ao invés de falarmos em impassibilidade do sábio, devamos falar em invulnerabilidade do mesmo. Ainda assim, o âmago da questão política permanece intacto. Impassível ou invulnerável o sábio não é indiferente. E a política, mesmo considerada um indiferente para a aquisição da virtude absoluta, tem

\footnotetext{
${ }^{14}$ Diz Sêneca: “As pessoas inexperientes [os não sábios] vêem-se em grandes dificuldades para superar as dores físicas precisamente porque não se acostumaram a contentar-se com a vida da alma, e dão portanto ao corpo grande importância. Por isso mesmo, o homem entregue de coração à sabedoria separa a alma do corpo e ocupa-se mais da primeira - sua parte melhor, de natureza divina -, e apenas dá ao corpo - frágil e sempre queixoso" - os cuidados estritamente indispensáveis." SÊENECA, Epist. 78, 10. O sábio tem dor, mas não compromete sua virtude por ela.

15 SÊNECA. Epist. 71, 29.

16 SÊNECA, Epist. 9, 2-3.

${ }^{17} \mathrm{Idem}, \mathrm{Ibdem}$.

18 Id. Ibdem. "Hoc inter nos et illos interest: noster sapiens vincit quidem incommodum omne sed sentit, illorum ne sentit quidem”.
} 
valor na ética, na medida em que pode contribuir com o desenvolvimento moral dos homens comuns e constitui, por isso, um importante espaço de ação do sapiens. Em termos técnicos, o correto é afirmar que o sábio é invulnerabilis aos indifferens, mas nunca indiferente ou insensivel ao politico. Como nos diz Laurand:

"Se engajar na cidade, de uma maneira ou de outra, é uma consequência lógica da oikeiosis [apropriação de si mesmo] e do sentimento natural de justiça que isso engloba: a natureza chama desde os primeiros impulsos e, uma vez que a cidade [comum] constitui esse tipo de ponto de união que permite aos insensatos conhecer aproximadamente a ligação social que ela exige, a cidade particular se transforma em lugar privilegiado, mas ambíguo, de ação do sábio."19

Pensar o estoicismo como apolítico tem ainda uma outra motivação e diz respeito ao significado de paixão (afectum, pathos) ${ }^{20}$. Sêneca, por exemplo, ao analisar a ira oferece uma detalhada explicação do funcionamento das paixões, sua significação exata e o que pode ou não ser considerado uma paixão. Esta questão é central, na medida em que nos permite compreender tudo aquilo que o sábio estoico deve ou não sentir. A ira, assim como as demais paixões, não são movimentos fortuitos da alma, tais como o riso espontâneo ou o entristecerse frente aos suplícios ou encenações teatrais. Sobre todas estas coisas, Sêneca afirma que "são movimentos de almas que, todavia, não querem ser movidas; não são paixões, mas princípios que preludiam as paixões." ${ }^{21}$ Pois, como sabemos, as paixões, assim como os vícios, são movimentos voluntários da alma. À estes movimentos voluntários é que o sábio deve resistir, deve combater com ânimo forte. Assim, o alegrar-se ou entristecer-se frente aos sofrimentos ou júbilos dos homens, o querer bem sua pátria, o amor aos filhos, cônjuges e cidadãos, a amizade, a raiva frente as injustiças diárias, tudo isso pode e deve ser sentido pelo sábio. Pois, como diz nosso autor:

"Nada dessas coisas que impelem fortuitamente a alma devem ser chamadas de paixões: a alma, por assim dizer, sofre-as mais do que as produz. Portanto, a paixão não é ser movido em função de imagens que nos ocorrem dos fatos, mas entregar-se a elas e seguir esse movimento fortuito. Realmente, se alguém considera um indício de paixão e um sintoma do estado da alma a palidez e

\footnotetext{
${ }^{19}$ LAURAND, L. La politique stöicienne. pp. 125-126.

${ }^{20}$ Paixão, muitas vezes tradizida em latim como perturbatio animi, é a grosso modo uma implusão irracional que excede a harmonia da razão, tanto do homem, como do mundo. E, por isso, deve ser compreendida como algo contra a anturza. C.f. DIÓGENES LAÉRCIO, Vidas e doutrinas dos filósofos ilustres. VII, 110.

${ }^{21}$ Sêneca, De Ira. II, 2, 5.
} 
as lágrimas caindo, a excitação de um desejo obsceno ou um suspiro profundo, um olhar repentinamente mais acerbo ou algo semelhante a tais coisas, engana-se e não entende que estes são impulsos do corpo." ${ }^{22}$

O sábio, portanto, sente igualmente estes prelúdios das paixões, da mesma forma que os homens comuns. No entanto, a diferença é que o sábio não dá o seu assentimento à este primeiro movimento da alma. Isto é, os mantém sob o julgo da razão. O sábio somente dá o seu assentimento às representações catalépticas ${ }^{23}$, ao verdadeiro. Esse é um dos motivos que faz com que os filósofos estoicos afirmem que somente o sábio tem ciência, somente o sábio conhece verdadeiramente. O sábio estoico seria, neste sentido, бoழós (sophós - sapiens). Por ter este conhecimento perfeito, por dar somente seu assentimento às representações verdadeiras, por conformar-se inteiramente à Natureza é que se diz que toda a ação empreendida pelo sábio é uma ação correta (kathortoma - rectum/perfectum officium). Neste sentido, a invulnerabilidade do sábio tem relação direta com a aceitação das determinações da Natureza, com a aceitação voluntária dos desígnios da fortuna.

"O sábio não se lamenta se lhe acontecer algo daquilo que a condição humana está sujeita. Conhece as próprias forças, sabe que não vergará sob o peso. Com isso eu não estou a colocar o sábio à parte do comum dos homens nem a julgá-lo inacessível à dor como se de um penedo insensível se tratasse. Apenas recordo que o sábio é formado de duas partes: uma é irracional, e sensível, portanto, às feridas, às chamas, à dor; outra é racional, dotada de convicções inabaláveis, inacessível ao medo, indomável. É nesta parte que reside o supremo bem para o homem."24

O sábio, neste sentido, é aquele atingiu a perfeição de sua racionalidade, que a elevou ao seu mais alto grau, realizando sempre ações retas e virtuosas. Em outras palavras, é aquele que realizou seu bem específico enquanto homem, que alinhou-se à razão universal. Diz Sêneca:

"No homem, enalteçamos só aquilo que se lhe não pode tirar, nem dar, aquilo que é específico do homem. Queres saber o que é? É a alma e, na alma, uma razão perfeita. O homem é, de fato, um animal possuidor de razão; por

\footnotetext{
22 SÊNECA, De Ira. II, 3, 1.

${ }^{23}$ Do grego phantasia kataleptike ( $\left.\varphi \alpha \nu \tau \alpha \sigma i \alpha \varkappa \alpha \tau \alpha \lambda \eta \pi \tau \iota \dot{\eta}\right)$ ), traduzido para o latim por visum comprehendibile. C.f. CÍCERO, Academica, I, 40-41.

${ }^{24}$ SÊNECA. Epist. 71, 26-27. (S.V.F II, 762) (S.V.F II, 879 e III, 20) e também Epist. 72,5.
} 
conseguinte; se um homem consegue a realização do fim para que nasceu, $\mathrm{o}$ seu bem específico atinge a consumação. A razão não exige do homem mais do que esta coisa facilima: viver segundo a sua própria Natureza!’25.

O sábio difere-se do insensato por suas ações, pela conformidade que mantém com a natureza. Pois, como sabemos, "o bem supremo consiste em viver de acordo com a Natureza"26. Viver de acordo com a Natureza equivale dizer, segundo os estoicos, que o fim último de cada ser vivo é viver conciliando-se tanto à sua própria Natureza, quanto à physis universal, constantemente atualizando-a. Viver de acordo com a natureza, para o homem e contrariamente aos animais seria, portanto, viver de acordo com a razão, dado que a racionalidade é uma característica humana que deve ser levada à perfeição. Seria uma espécie de apropriação de si mesmo, apropriação das qualidades e características que são exclusivas daquele ente vivo ${ }^{27}$. Ora, o que haveria de mais específico aos seres humanos? Sêneca nos responde ao dizer que o "homem é, de fato, um animal possuidor de razão"28. Desta forma, a racionalidade é apontada como característica exclusiva dos homens (bem como dos Deuses), uma vez que o logos humano é um fragmento do logos divino, da ratio universal ${ }^{29}$. Assim, é no exercício da razão que o homem encontrará o bem supremo, é conciliando-se e apropriando-se à sua própria physis (racional) que ao mesmo tempo ele se apropriará e participará da razão universal. O sábio, neste sentido, é aquele que levou sua natureza específica à sua excelência, conformando-a com a Natureza universal. Ele é, por fim, pura racionalidade em seus atos, apesar de, como já vimos, demonstrar sentimentos. O sábio, aquele que age exclusivamente sob o crivo da razão, é exemplo daquilo que os homens devem alcançar. Aliás, Sêneca sempre coloca a figura do sábio como exemplo a ser seguido, como modelo no qual devemos nos espelhar. Diz o autor: "Que a nossa alma, portanto, tenha um modelo a quem venere e graças a cuja autoridade torne mais nobre mesmo o seu mais íntimo recesso." ${ }^{30}$ Por fim, devemos compreender que o sábio tem função paradigmática, desempenhando uma espécie de paradigma pedagógico para a formação dos homens. O sábio é aquele exemplo para o qual todas as ações que se pretendem corretas concorrem. Ele seria, em nossa interpretação, o ponto de fuga das ações dos homens insensatos, indicando o caminho a ser seguido para que a sabedoria seja alcançada.

\footnotetext{
25 SÊNECA. Epist.41,8

${ }^{26}$ SÊNECA. De Otio. V, 1. (Solemus dicere summum bonum esse secundum naturam uinere: natura nos ad utrumque genuit, et contemplationi rerum et actioni.)

${ }^{27}$ Trata-se aqui, mais uma vez, da ideia estoica de oikeiosis - conciliatio.

${ }^{28}$ SÊNECA. Epist. 41, 8.

${ }^{29}$ SÊNECA. Epist. 76, 9.

${ }^{30}$ SÊNECA. Epist.11, 9.
} 
Percebe-se, portanto, que a figura do sábio estoico deve ser interpretada muito mais com contornos modelares que propriamente factuais, caso queiramos estabelecer a política como central na ética estoica. Se, como pensam aqueles que não creditam ao estoicismo uma preocupação política, a única forma válida de pensar a cidade ${ }^{31}$ fosse aquela na qual somente o sábio e sua excelência moral constituíssem um verdadeiro corpo político, então seria insubsistente toda prática política mundana, com suas cidades particulares e suas comunidades. Isto é, "nós podemos pensar que toda cidade se encontra invalidada nos seus fundamentos frente à excelência da Natureza e do sábio, uma vez que ela (a cidade comum) reúne uma esmagadora maioria de insensatos." 32 Em outras palavras, levando às últimas consequências a partição entre pequena cidade (a cidade comum, particular) e a grande cidade, o cosmos, chegamos à conclusão que o único espaço de participação política possível para o sábio é aquele "reduzido à uma moral perfeita, que consiste em colaborar ao destino e a ser cidadão do mundo" ${ }^{33}$. Sob este ponto de vista, o sábio deveria se afastar dos assuntos mundanos, da política particular e, portanto, indiferente ${ }^{34}$ aos propósitos de um homem virtuoso. Caímos novamente naquela imagem do estoico fechado em si mesmo, mais preocupado com o ideal de virtude professado pela doutrina que pela vida cotidiana. Caímos na ideia do sábio que não investe suas forças na res publica que o cerca uma vez que esta é imperfeita e habitada por insensatos, fazendo-nos pensar que nunca alcançaremos a virtude.

Pensar a ética e, portanto, a política estoica em termos tão extremados, como na oposição vício / virtude, insensato / sábio, é, primeiramente, reduzir muito o poder de reflexão da stoa e, além disso, não compreender bem o cerne da escola, o caráter pedagógico e ambíguo de seu discurso ${ }^{35}$. Afinal, que sentido teria aconselhar aquele que atingiu a perfeição moral e a vida virtuosa (sábio) ou, na outra extremidade, o completo insensato, o homem comum? Se de um lado temos o sábio que, como vimos, realizou plenamente sua finalidade específica, exercendo sua racionalidade de forma a viver de acordo com a Natureza, de outro temos os homens comuns, não sábios, imensa maioria existente nas

\footnotetext{
31 Devemos lembrar que, no estoicismo em geral e igualmente para Sêneca, o tema das duas repúblicas é sempre presente. Em sua filosofia, deve ser entendido que existe a cosmópolis, fruto da universalidade da razão no homem, fazendo com que, no limite, todos sejamos iguais independentemente de qualquer outro atributo, social ou espacial. E a república particular, como as pequenas cidades (Roma, Atenas, etc.). Explica o autor: "Em espírito aprendemos duas repúblicas: uma, grande e verdadeiramente pública, que abarca deuses e homens, na qual não nos confinamos a este ou àquele canto, mas na qual os raios do sol marcam os limites de nossa cidade; outra, à qual nos atribui nossa condição de nascimento (essa será a dos atenienses ou dos cartagineses ou alguma outra cidade qualquer), que não se estende a todos os homens, mas a alguns determinados." SÊNECA, De otio. IV, 1.

${ }^{32}$ LARAUND, V. La politique Stö̈cienne. p.06.

${ }^{33}$ LARAUND, V. La politique Stoücienne. p.06.

${ }^{34}$ Do grego adiaphora ( $\alpha \delta i \dot{\varphi} \varphi \varrho \varrho \alpha$ - indiferentes).

${ }^{35}$ C.f. GAZOLLA, R. O Ofício do filósofo estoico: O duplo discurso da stoa. Ed. Loyola. São Paulo: 1999
} 
cidades. Frente à condição raríssima e até mesmo duvidosa da existência do sábio, os estoicos admitiam um conceito fundamental para resguardar o espaço de ação moral entre homens comuns. Trata-se da ideia de progresso moral. Pois, se a sabedoria absoluta, tal qual como concebida e exercida pelo sábio, é inacessível aos homens; a estes cabe o exercício dos deveres como meio de agir virtuosamente.

Sem entrar no mérito das ações perfeitas (katorthomata), das ações que são exclusivas de sábios e deuses por serem absolutamente perfeitas, voltemos nossos olhos para as ações possíveis, as ações dos homens comuns, vivendo em sociedade. Seria possível resguardar um espaço para a moral entre eles? Se pensarmos a ação virtuosa como exclusiva do sábio, toda a ação entre homens comuns perde sua força. No entanto, se considerarmos que, aquém da excelência do sábio existe a possibilidade de uma virtude entre os homens, então será possível dotar as ações comuns de algum valor moral, ainda que relativo frente ao valor absoluto da virtude. Tais ações "relativas", acessíveis a todos os homens, é o que permite o plano político e moral aos insensatos. Estamos tratando, portanto, não da cosmópolis e do sábio (com suas ações perfeitas), mas da res publica particular e dos homens comuns (com suas ações suscetíveis ao erro).

Entre as ações comuns, umas são preferíveis por estarem mais próximas da natureza, outras devem ser evitadas por serem prejudiciais ao alcance da virtude, outras ainda são completamente indiferentes. Para alcançarmos a virtude e o bem viver seria preciso alinharmo-nos o máximo possível de nossa physis, tanto particular, quanto universal. Deveríamos, caso quiséssemos ser homens virtuosos, agir de acordo com a razão, agir o mais alinhado possível com a ratio universal. A este agir de acordo com a razão os estoicos chamam de kathēkonta (ações preferíveis) em grego, termo traduzido por Cícero por commune officium, ou simplesmente officium, e por Sêneca pela palavra convenentia. Tendo, todos esses vocábulos o mesmo significado: agir, na medida do possível, de forma a apropriar-se de sua própria natureza, atualizando-a e conciliando-se a ela. Frente à excelência da figura do sábio (oọóssapiens) e da perfeição de suas ações, é colocada a figura do homem prudente, guiado pela

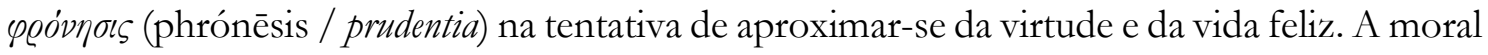
equivale, entre homens insensatos, a um código de conduta prática, por meio do qual aqueles que tiverem boa vontade em alcançar a virtude poderão se exercitar. Dessa forma, diz Banateanu:
"existe um lugar para uma virtude humana ao lado da virtude do sábio, uma

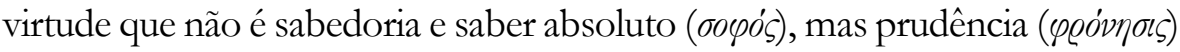 e reflexão racional. Esta prudência consiste em fazer todo o nosso possível para atingir o objetivo a natureza que nos é proposta." 36

${ }^{36}$ BANATEANU, Anne. La théorie stoïcienne de l'amitié. Essai de reconstruction. p. 62. 
Com isso, temos o desenvolvimento de uma filosofia que torna-se cada vez mais parenética, mais preocupada e "especializada nos preceitos concernentes a vida cotidiana" 37 . Pouco a pouco o estoicismo vai se afastando das especulações metafísicas para se concentrar em conselhos práticos, para transformar-se em ars vivend $i^{38}$. Afinal, a filosofia, assim como a virtude, não é obra do acaso. Ambas pressupõe um árduo caminho para ser trilhado ${ }^{39}$. Para Sêneca, a natureza não nos dá a virtude: alcança-la é tarefa dos homens, é tarefa da filosofia. É por meio de suas ações, da correta escolha delas, da prática das kathēkenta que o homem poderá aproximar-se da virtude e obter uma vida feliz. Mas, não nos enganemos, para usar uma frase de nosso autor: "A via que conduz ao cume da dignidade é extremamente árdua" e, caso se queria obter êxito em alcançar a virtude, é preciso tanto conhecer, quanto agir. Ao homem comum, que tanto não conhece como não age de forma perfeita (em contraposição ao sábio - este sim que possui o verdadeiro conhecimento e é capaz de realizar ações perfeitas, como vimos) é preciso, caso queira progredir rumo ao "cume da dignidade" levar uma vida de acordo com a Natureza. Isto é, uma vida de racionalidade.

O bem viver estaria, deste ponto de vista, absolutamente ligado ao exercício da filosofia, uma vez que, diz o filósofo, "não há filosofia sem virtude, nem virtude sem filosofia" ${ }^{40}$. A prática filosófica seria, na concepção do autor romano, o meio por excelência de alcançar a tão almejada vida virtuosa e são muitos os trechos que nos afirmam que o exercício da filosofia é o meio mais eficaz para alcançarmos a vida feliz. Sêneca nos comenta: "Quem duvidará, Lucílio amigo, que, se devemos a vida aos deuses imortais, é à filosofia que devemos a vida virtuosa?" comuns dos homens. Funcionaria como condutora das ações virtuosas. Diz Sêneca: "ela [a filosofia] ordena a vida, regula a ação, mostra o que deve ser feito e o que deve ser evitado, está no leme e dirige o curso hesitante dos que erram a esmo" "42. A filosofia seria a arte do bem viver, longa arte (como bem lembrado por Sêneca ao retomar a famosa frase de Hipócrates: "a vida é breve, longa é a arte”43), arte que permitiria ao homem alcançar a virtude, sendo o filósofo um "artista da vida" ${ }^{44}$, artista do bem viver.

No entanto, como sabemos, a filosofia não se trata de arte ociosa, desprendida da vida em comum. Ela é, ao mesmo tempo, modo de ação. Esta exortação à filosofia não se

\footnotetext{
${ }^{37}$ BANATEANU, Anne. La théorie stoïcienne de l'amitié. Essai de reconstruction.. p. 62.

${ }^{38}$ Falamos aqui da ideia segundo a qual a filosofia adquire a função de terapia da alma, calcada em seu aspecto de aconselhamento moral. 
identifica com a contemplação alheia à atividade pois, ainda segundo a concepção filosófica estoica, não poderia existir contemplação sem ação. O próprio exercício da filosofia seria, em última instância, movimento e ação alinhados à contemplação da Natureza. Fato que está plenamente de acordo com os gêneros de vida expostos pela doutrina estoica ${ }^{45}$. Pois, para os estoicos, a vida que se guia pelo logos reveste tanto a prática, quanto a teoria. Trata-se do

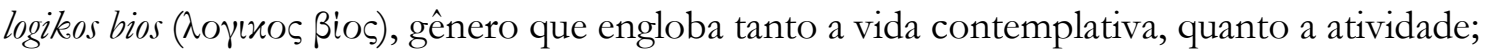
tal qual Sêneca descreve a verdadeira filosofia. Afinal, a vida racional, como sabemos, é a vida pautada pela natureza e, ainda de acordo com Banateanu, "viver de acordo com a natureza é viver de acordo com a razão e esta nos guia tanto na teoria, quanto na prática. A virtude é, portanto, ao mesmo tempo teorética e prática." ${ }^{46}$ Igualmente a "a filosofia", diz Sêneca, "ensina a agir, não a falar" partes, pois Sêneca a define levando em consideração teoria e prática. Diz nosso autor: "A virtude reveste dois aspectos: um, a contemplação da verdade, outro a ação"48.

A filosofia seria, portanto, o meio por excelência para alcançar a vida virtuosa. Vida esta que une em si tanto a apropriação da physis, da atualização em si da ratio universal, quanto o dever da ação, o dever de ser útil senão ao maior número possível de outros homens, no mínimo a si próprio. Diz Sêneca:
“Assim, vivo segundo a Natureza, já que a ela me entreguei totalmente, já que sou eu seu admirador e servo. Entretanto, a natureza quer que eu faça duas coisas: agir e dedicar-me à reflexão. Tanto uma quanto a outra eu realizo, pois não pode haver contemplação sem alguma forma de ação". ${ }^{49}$

Não se trata de pura dogmata, mas igualmente de conselhos capazes de guiar ações. Há, portanto, uma indissociabilidade entre o plano da reflexão e o plano da ação política, tal como existe uma indissociabilidade entre a teoria e a prática. Na visão de Sêneca, dedicar-se à Filosofia é, ao mesmo tempo, entregar-se à um tipo de ação. Se não é possível estar diretamente envolvido nos assuntos da corte ou enfurnado nos palácios, ainda assim é possível agir. Ainda assim é possível intervir. Pois, como sabemos, os estoicos acreditavam

\footnotetext{
${ }^{45}$ Diz Diógenes Laércio que, dente os três gêneros de vida descritos pelo estoicismo, o melhor para alcançar a verdadeira felicidade é o gênero racional. Diz o autor: "Dos três modos de vida - o contemplativo, o prático e o raiconal - os estóicos dizem que se deve escolher o terceiro, pois a natureza criou o ser racional adaptado para a contemplação e a ação DIÓGENES LAÉRCIO, Vidas e doutrinas dos filósofos ilustres. VII, 130.

46 BANATEANU, Anne. La théorie stoïcienne de l'amitié. Essai de reconstruction.. p. 86.

${ }^{47}$ SÊNECA. Epist. 20

48 SÊNECA. Epist. 94, 45. Vale lembrar que a discussão de pracepta x dogmata é recuperada e sistematizada por Sêneca nas cartas 94 e 95 de suas Epistulae.

${ }^{49}$ SÊNECA. De Otio. IV
} 
que uma das formas (talvez a mais sublime) de cumprir as determinações da Natureza era entregar-se ao estudo da filosofia, uma vez que a contemplação filosófica tem em si mesma a característica de servir ao conjunto dos homens em tempos futuros, de intervir em suas sociedades, de os formar.

"A Filosofia não é uma habilidade para exibir em público, não se destina a servir de espetáculo; a filosofia não consiste em palavras, mas em ações. $\mathrm{O}$ seu fim não consiste em fazer-nos passar o tempo com alguma distração, nem em libertar o ócio do tédio. O objetivo da filosofia consiste em dar forma e estrutura à nossa alma, em ensinar-nos um rumo na vida, em orientar os nossos atos, em apontar-nos o que devemos fazer ou pôr de lado, em sentarse ao leme e fixar a rota de quem flutua à deriva entre escolhos. Sem ela ninguém pode viver sem temor, ninguém pode viver em segurança. A toda hora nos vemos em inúmeras situações em que carecemos de um conselho: pois é a filosofia que no-lo pode dar." ${ }^{30}$

Desta forma, a contemplação filosófica e a vida dedicada à Filosofia seria, de acordo com o estoicismo de Sêneca, igualmente uma vida de ação e - em última instância, uma vida de ação política, uma vez que, sendo a filosofia o instrumento para o aperfeiçoamento moral dos homens, seria da mesma forma instrumento de aperfeiçoamento político deles. Por meio do ensino da virtude, tarefa por excelência da filosofia, pode-se pensar em transformar cidadãos particulares em cidadãos do mundo, universalizando-os pela ampliação (apropriação) de sua racionalidade. E, como já dissemos, também a política pode ser interpretada enquanto instância indiferente que pode propiciar o acesso dos insensatos à justiça, pelo menos. É sempre preferível, portanto, ter uma vida ativa, manter-se em movimento. Pois a política e a res publica particular, mesmo sendo considerados indiferentes para a aquisição da virtude e da vida feliz, ainda assim resguardam algum valor entre os homens comuns, já que podem ser interpretadas enquanto indiferentes aos quais atribuímos valor relativo. A política é, portanto, um preferivel. E, sendo um preferível, devemos sempre buscala em nossas ações de homens comuns, em nossos deveres. A política, neste sentido, deve ser compreendida assim como a filosofia, como instrumento que permitiria o desenvolvimento moral dos homens. Neste sentido, o ócio é indicado pelos estoicos apenas quando toda e qualquer tentativa de ação na esfera pública se mostrar inócua. E, ainda assim, o sentido da palavra ócio merece uma interpretação cuidadosa: não se trata de ócio indiferente, mas sim de

${ }^{50}$ SÊNECA. Epist.16, 3. 
um retiro da vida pública imediata tendo em vista uma ação posterior ${ }^{51}$. Pois Sêneca, retomando os ensinamentos de Zenão e Crisipo, diz que também no ócio pode-se empreender grandes feitos.

\section{Diz o autor:}

"Somos nós [os estóicos] certamente que afirmamos tanto de Zenão quanto de Crisipo terem feito eles maiores coisas do que se tivessem conduzido exércitos, exercidos cargos honrosos, promulgado leis - que aliás eles promulgaram, não para uma só cidade, mas para todo o gênero humano." ${ }^{52}$

Isto é, mesmo sem tomar parte nos negócios públicos, tais filósofos, nos lembra Sêneca, "não levaram vida inerte: descobriram o modo de tornar sua inatividade mais útil aos homens que a agitação e o suor de outros." 53 É preciso, não somente ter em mente os ensinamentos da filosofia, mas igualmente coloca-los em prática ${ }^{54}$.

Toda a discussão se concentra na seguinte relação: o sapiens está para a sociedade do gênero humano assim como o filósofo está para os homens da res publica. Isto é, se de um lado temos o sábio como o exemplo das ações morais para os homens da cosmópolis, de outro temos o filósofo como condutor das ações convenientes nas sociedades particulares. De acordo com esta interpretação, vemos que o papel educador do filósofo se sobressai. E, para além da ideia comumente atribuída ao filósofo estoico (igualmente ao sapiens) como retirado e impassível frente aos sofrimentos do mundo, ganha espaço o filósofo que possui uma das mais nobres funções, a educação. É construída a imagem da filosofia como formadora dos homens, na qual o filósofo assumiria a função de pedagogo. Não qualquer pedagogo, mas o filósofo teria como função o ensinamento da virtude. Diz Sêneca, ao comentar sobre as artes de sua época ${ }^{55}$, que a única arte verdadeiramente liberal é aquela que garante a liberdade do

\footnotetext{
$51 \mathrm{O}$ otuim proposto por Sêneca igualmente não se confunde com o lazer. A vida dedicada à filosofia é louvável e, mesmo nela, a utilidade é estimada. Ao comentar o caso de Vátia, famoso figurão romano que resolvera afastar-se de Roma e retirar-se da vida política e social, de modo a não ser atormentado pelos problemas comuns, Sêneca fala à Lucílio: "Não, Vátia sabia esconder-se, isso sim, mas não viver; pois há uma enorme diferença entre viver no ócio ou viver na indolência.” In: SÊNECA. Epist. 55, 4.

52 SÊNECA. De Otio. VI, 1.

53 SÊNECA. De Otio. VI, 5.

54 Diz Sêneca: "A pior crítica que nos podem fazer é a acusação de repetirmos as sentenças da filosofia sem pormos em prática seus ensinamentos.” In: SÊNECA. Epist. 24,15. Além do mais, a ação é sempre permitida e possível, seja ao sapiens, seja ao filósofo. Pois, diz nosso autor, "mesmo que algumas dificuldades o aflinjam, nem assim o sábio é impedido de ser útil aos outros." In: SÊNECA. Epist. 85, 38.

${ }^{55}$ SÊNECA. Epist. 88, 4-5. Diz o autor romano neste trecho: "Vejamos se os mestres das artes liberais ensinam ou não a virtude; se não a ensinam, não podem transmiti-la; se a ensinam, então são filósofos.”
} 
homem, ou seja, a filosofia: "A recompensa que te promete a filosofia é de longe superior: a liberdade permanente, a ausência de receio quer ante os homens, quer ante os deuses." ${ }^{\prime 56} \mathrm{E}$, não se pode deixar de comentar, tal arte é acessível à todos os homens. Deste modo, todos os homens, de qualquer república particular, podem agir virtuosamente se quiserem. É a universalidade da razão que possibilita os laços entre os homens, ainda que inconscientes. Aos filósofos, portanto, cabe exortar os homens a ter consciência destes laços, cessando de ceder às tendências de isolamento e solidão ${ }^{57}$. Pois é retomando a natureza social dos homens (koinonikós) que será restabelecida sua face política, para além da particularidade de qualquer República. A tarefa do filósofo, ao ensinar a virtude (ao ensinar a vida de acordo com a natureza), possibilita ações preferíveis e faz do espaço político (das sociedades particulares) uma instância capaz de resguardar o acesso à justiça e a equanimidade entre homens comuns (não sábios). Dedicar a vida ao ensino da filosofia é, neste sentido, uma das mais nobres atividades, dignas de uma grande alma. Pois, é na árdua tarefa do filósofo que, passando do modelo à ação, podemos vislumbrar a possibilidade da política, da boa política.

\section{FROM MODEL TO ACTION: POLITICS IN SENECA AND THE PRAISE OF PHILOSOPHY}

Abstract: In this article, we intend to demonstrate that stoicism is not a philosophy apart from political action, but, on the contrary, it is a philosophical current committed to the public sphere. In an attempt to exalt the role played by philosophy in the political formation of ordinary men, we seek to analyze Seneca's thinking in view of the established relationship between the modeling figure of the stoic sapiens and the philosopher's office in the construction of a field of political action.

Keywords: Seneca - Stoicism - Philosophy - Sapiens - Politics.

\section{REFERÊNCIAS BIBLIOGRÁFICAS}

CÍCERO, M. T. De Officiis (Dos Deveres). Trad e notas Angélica Chiapeta. São Paulo: Martins Fontes, 1999.

De Finibus bonorum et malorum (Do sumo bem e do sumo mal). Trad. e notas Carlos Ancide Nougué. São Paulo: Martins Fontes, 2005.

\footnotetext{
${ }^{56}$ SÊNECA. Epist. 17,6

${ }^{57}$ C.f.: Chronis, N. (1984). p. 60. "Em resumo, o homem é um animal social não porque ele vive em sociedade, mas o homem vive em sociedade porque é um animal naturalmente sociável por sua participação ao logos universal.” In: BANATEANU, Anne. La théorie stö̈cienne de l'amitié. Essai de reconstruction. p. 100.
} 
. Academicas. Tradução, introdução e otas: José Seabra Filho. Belo Horizonte: Nova Acrópole, 2012.

BANATEANU, Anne. La théorie stö̈cienne de l'amitié. Essai de reconstruction. Fribourg Éditions Universitaires. Le Cerf. Paris: 2001

BROUWER, R. "Sagehood and the Stoics". In: OSAPh 23, 2002. pp.181-224.

DIÃO CÁSSIO, Historia Romana. Trad. Earnest Cary. Cambridge: Loeb Classical in 9 vol, 1990.

DIÓGENES LAÉRCIO, Vidas e Doutrinas dos Filósofos Ilustres. Tradução do grego, introdução e notas: Mário da Gama Kury. 2a Edição. Brasília: Editora Universidade de Brasília, 2008.

ERSKINE, A. The helleistic Stoa:political thought and action. Ed. Duckworth \& Co. London: 1990 HADOT, I. Sénèque: Direction spirituelle et pratique de la philosophie. Paris: Vrin, 2014.

HIPÓCRATES. Aforismos. Tradução de Joffre Marcondes de Rezende. Campinas: Editora UNICAMP, 2010.

LAURAND, V. La politique stö̈ienne. Paris: Presses Universitaires de France - PUF, 2005.

Le vocabulaire des stö̈ciens. Paris: Ed. Ellipses, 2002.

PLUTARCO, Against the stoics. Trad. Harold Cherriss. Cambridge: Loeb Classical Vol. XIII, 1997 . On Stoic self contradictions. Trad. Harold Cherriss. Cambridge: Loeb Classical Vol. XIII, 1997 .Oeuvres Morales. Paris: Belles Lettres, 19-?.

REYDAMS-SCHILS, G., The Roman Stoics: Self, responsibility and affection. Chicago: University of Chicago Press. 2005.

RODIS-LEWIS, G. La Morale Stoïcienne. Paris: PUF, 1970

SANCHEZ, M. F. M. El Ideal del Sabio en Seneca. Publicaciones de la Excma. Diputación Provincial de Córdoba. Córdoba: 1984.

SCHOFIELD, M. “A ética estóica”. In: Inwood, B. (org.). Os Estoicos. Tradução de Paulo Fernando T. Ferreira. São Paulo: Odysseus, 2006. 
SELLARS, J. The art of living: The stoics on the Nature and function of philosophy. Ashgate Publishing Limited, 2003.

SÊNECA. Cartas Consolatórias: Consolação a Márcia, Hélvia e Políbio. Tradução de Cleonice Furtado Mendonça Van Raij.Campinas : Editora Pontes, 1992.

De Brevitate Vitae (Sobre a Brevidade da Vida). Edição Bilíngue. Tradução, Introdução e Notas: Willian Li. São Paulo: Nova Alexandria, 1993.

De Ira (Sobre a Ira). Tradução, introdução e notas de José Eduardo S. Lohner. São Paulo : Penguin Classics Companhia das Letras, 2014.

De la constance du sage. (De constantia sapientis). Traduzido por Émile Bréhier e Editado por Pierre-Maxime Schuhl. Paris : Gallimard, 2006.

De Otio (Sobre o ócio). Tradução, apresentação e notas de José Rodrigues Seabra Filho.

Edição Bilíngue. São Paulo : Nova Alexandria, 2001.

De Tranquillitate animi. (Sobre a tranquilidade da alma). Tradução, introdução e notas de José Eduardo S. Lohner. São Paulo : Penguin Classics Companhia das Letras, 2014.

De Vita Beata (Sobre a vida feliæ). Edição Bilíngue. Tradução, Introdução e Notas: João Teodoro D’Olim Marote. São Paulo: Nova Alexandria, 2005.

. Epistulae Morales (Cartas a Lucílio). Tradução e notas de J. Segurado e Campos. $4^{a}$ edição. Lisboa: Fundação Calouste Gulbenkian, 1991.

Tutte le opere. (Dialoghi, trattati, lettere e opere in poesia). A Cura di Giovanni Reale. Milano: R.C.S. Libri S.p.A. Ed. Bompiani, 2000.

VOELKE, A.-J. La Philosophie comme thérapie de l'âme: études des philosophie hellénistique. Fribourg: Editions Universitaires, 1993.

VOGT, K. M., Law, Reason, and the Cosmic City: Political Philosophy in the Early Stoa. New York: Oxford University Press. 2008 